\title{
PENGGUNAAN TERAPI SENAM OTAK PADA ANAK DENGAN MASALAH PENURUNAN KONSENTRASI BELAJAR DI DESA RAWAJITU SELATAN
}

\author{
Lidya Arianti ${ }^{1}$, Redia Indira Putrianti ${ }^{2}$, Setiawati ${ }^{3^{*}}$ \\ ${ }^{1}$ Program Studi Ilmu Keperawatan Universitas Malahayati \\ ${ }^{2}$ Mahasiswa Program Studi Ilmu Keperawatan Universitas Malahayati \\ ${ }^{3}$ Program Studi Ilmu Keperawatan Universitas Malahayati
}

Email Korespondensi: setiawati1477@yahoo.com.au

\begin{abstract}
ABSTRAK
Kosentrasi merupakan keadaan pikiran atau asosiasi terkondisi yang diaktifkan oleh sensasi di dalam tubuh. Cara mengaktifkan sensasi di dalam tubuh adalah dengan membuat tubuh berada dalam keadaan yang rileks dan suasana yang menyenangkan, karena dalam keadaan yang tegang seseorang tidak akan dapat menggunakan otaknya dengan maksimal oleh karena pikiran menjadi kosong. Fenomena yang terjadi di lapangan diketahui bahwa penurunan konsentrasi belajar pada anak belum mendapatkan penanganan yang maksimal. Selama ini teknik yang digunakan memiliki kelemahan tersendiri yang tentunya tujuan dari peningkatan konsentrasi belajar belum dapat dirasakan oleh semua siswa, seharusnya teknik peningkatan konsentrasi belajar di buat lebih mudah dan efektif. Salah satunya adalah teknik Brain Gym. Tujuan setelah diberikan terapi senam otak diharapkan dapat meningkatkan konsentrasi belajar pada anak. Adapun kegiatan yang dilakukan berupa penyuluhan dan demonstrasi terapi senam otak. Terdapat peningkatan konsentrasi belajar pada anak setelah diberikan terapi senam otak di Desa Rawajitu Selatan. Dengan demikian, pemberian terapi senam otak efektif dalam meningkatkan konsentrasi belajar.
\end{abstract}

Kata Kunci: Konsentrasi, Senam Otak, Peningkatan Konsentrasi Belajar

\begin{abstract}
Concentration is a state of mind or conditioned association that is activated by sensations in the body. How to activate sensations in the body is to make the body in a relaxed state and pleasant atmosphere, because in a tense situation a person will not be able to use his brain to the maximum because the mind becomes empty. The phenomenon that occurs in the field is known that the reduction in the concentration of learning in children has not gotten the maximum treatment. During this time the technique used has its own weaknesses which of course the purpose of increasing concentration of learning can not be felt by all students, the technique of increasing the concentration of learning should be made easier and more effective. One of them is the Brain Gym technique. The goal after being given brain exercise therapy is expected to increase the concentration of learning in children.
\end{abstract}


The activities carried out in the form of counseling and demonstration of brain exercise therapy. There is an increase in the concentration of learning in children after being given brain exercise therapy at Rawajitu Selatan Village. Thus, the administration of brain exercise therapy is effective in increasing concentration of learning.

Keywords: Concentration, Brain Exercise, Increased Learning Concentration

\section{PENDAHULUAN}

Keberhasilan suatu proses belajar dipengaruhi oleh kemampuan individu untuk memusatkan perhatian terhadap objek yang sedang dipelajarinya. Terkait dengan hal tersebut maka konsentrasi merupakan aspek yang penting bagi anak dalam mencapai keberhasilan belajar. Proses pembelajaran di sekolah, anak dituntut untuk dapat selalu memfokuskan perhatiannya terhadap mata pelajaran yang sedang dipelajari dengan baik, akan tetapi dalam kenyataannya belum semua anak mampu untuk memusatkan perhatiannya terhadap situasi belajar (Slameto, 2010; Megawati, Ike, \& Maunaturrohmah, 2017).

Kosentrasi merupakan keadaan pikiran atau asosiasi terkondisi yang diaktifkan oleh sensasi di dalam tubuh. Cara mengaktifkan sensasi di dalam tubuh adalah dengan membuat tubuh berada dalam keadaan yang rileks dan suasana yang menyenangkan, karena dalam keadaan yang tegang seseorang tidak akan dapat menggunakan otaknya dengan maksimal oleh karena pikiran menjadi kosong (Dennison, 2010 ; Bili\&Lengo, 2019).

Skala internasional dari hasil studi IEA (Internasional Association for the Evaluation of Educational Achievement) menunjukan bahwa konsentrasi dan ketrampilan membaca siswa kelas IV SD di Indonesia berada pada peringkat terendah. Rata-rata skor tes membaca untuk siswa SD: 75,55\% (Hongkong), 74,0\% (Singapura), 65,1\% (Thailand), 52,6\% (Filipina), dan 51,7\% (Indonesia). Anak-anak Indonesia ternyata hanya mampu menguasai 30\% dari materi bacaan dan mereka sulit sekali menjawab soal-soal berbentuk uraian yang memerlukan penalaran (Dennison, 2014; Megawati, Ike, \& Maunaturrohmah, 2017).

Penurunan konsentrasi belajar pada anak kebanyakan terjadi pada 11-13 tahun yang biasanya duduk di kelas IV - VI SD. Dimana pada masa itu timbul beberapa masalah, terutama pada siswa kelas V SD yang cenderung mengalami penurunan konsentrasi dalam belajar, hal tersebut disebabkan oleh meningkatnya tingkat kesukaran pelajaran yang mereka terima berkaitan dengan pelajaran yang akan menjadi materi dalam Ujian Nasional (Djamarah, 2011 ; Naufal, 2016).

Akan tetapi hal tersebut dapat dicegah dengan memperbanyak aktifitas gerak dan pemikiran yang melibat kanotak bagian kanan dan otak bagian kiri. Fenomena yang terjadi di lapangan diketahui bahwa penurunan konsentrasi belajar pada anak belum mendapatkan penanganan yang maksimal. Selama ini teknik yang digunakan memiliki kelemahan tersendiri yang tentunya tujuan dari peningkatan konsentrasi belajar belum dapat dirasakan oleh semua siswa, seharusnya teknik peningkatan konsentrasi belajar di buat lebih mudah dan efektif. Salah satunya adalah teknik Brain Gym (Desmita,2009 ; Naufal, 2016). 
Menurut Dennison (2008) dalam Megawati, Ike\& Maunaturrohmah (2017) Brain Gym adalah serangkaian gerak sederhana yang menyenangkan dan digunakan untuk meningkatkan kemampuan belajar dengan menggunakan keseluruhan otak. Faktorfaktor yang mempengaruhi belajar dibagi menjadi dua faktor yaitu faktor internal dan eksternal (Slameto, 2010). Adapun kondisi yang dialami klien adalah faktor internal yaitu faktor psikologis berupa daya konsentrasi belajar.

Berdasarkan latar belakang diatas penulis tertarik untuk melakukan "asuhan keperawatan komprehensif pada anak dengan masalah penurunan prestasi belajar disebabkan tingkat konsentrasi belajar menurun dengan menggunakan terapi senam otak di Desa Rawajitu Selatan Kabupaten Tulang Bawang tahun 2020 “ yang dilakukan oleh penulis sebagai bahan studi kasus yang merupakan suatu syarat dalam menyelesaikan studi Ners pada pendidikan Program Studi Ilmu Keperawatan Fakultas Kedokteran Universitas Malahayati.

\section{MASALAH}

Alasan peneliti memilih tempat penyuluhan tentang terapi senam otak dan demonstrasi terapi senam otak di Desa Rawajitu Selatan ialah karena dalam salah satu anggota keluarga peneliti memiliki masalah penurunan konsentrasi belajar, dimana tujuan umum dalam kegiatan ini diharapkan mampu menggambarkan asuhan keperawatan anak secara komprehensif meliputi tingkat konsentrasi belajar anak, dan tujuan khusus dalam kegiatan yaitu asuhan keperawatan, telaah jurnal untuk menentukan intervensi, evaluasi hasil aplikasi intervensi, perbandingan hasil intervensi pemberian terapi senam otak.

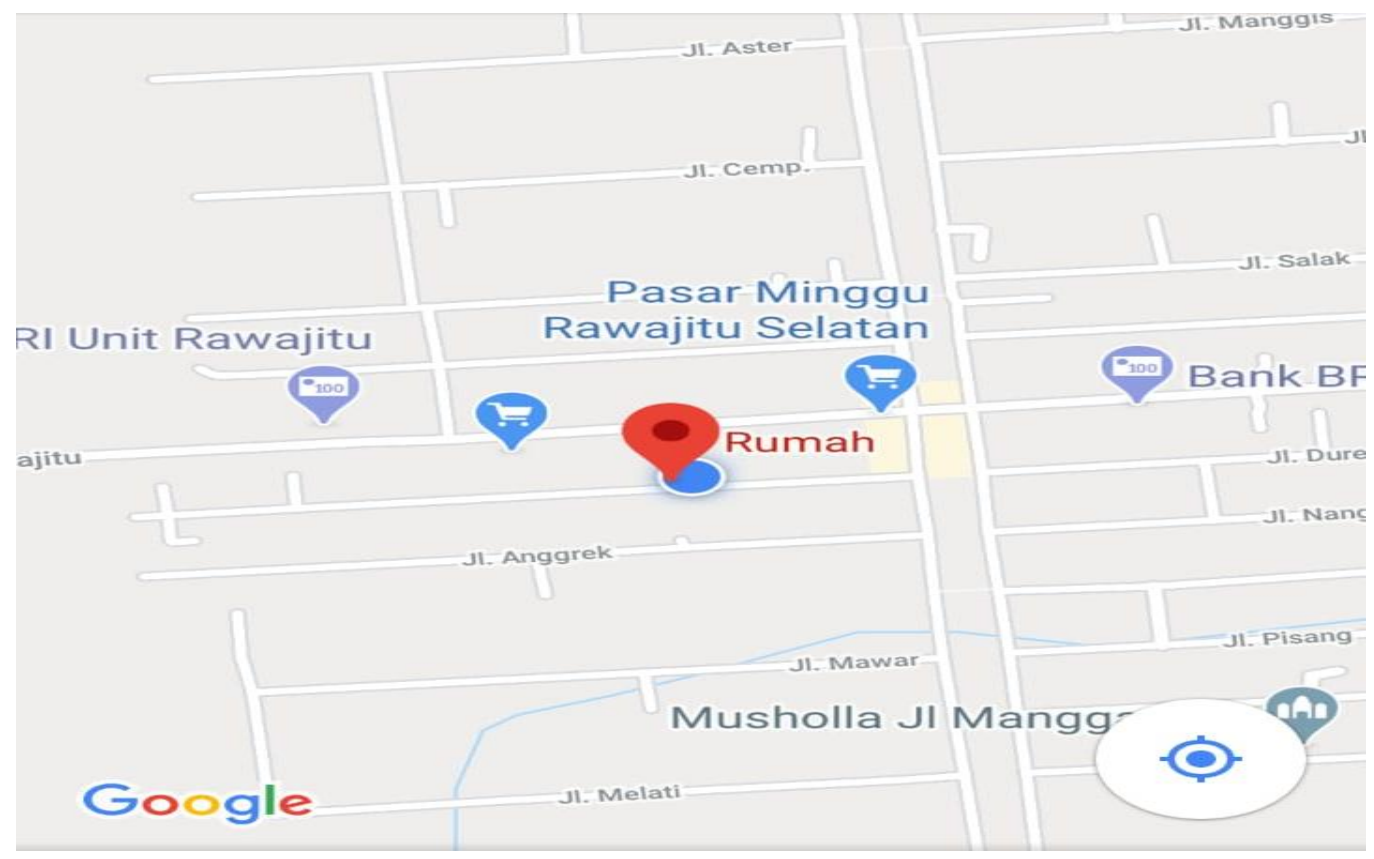

Gambar 2.1 Lokasi penyuluhan dan demonstrasi 


\section{METODE}

1. Tujuan Persiapan

Tahap persiapan dari kegiatan adalah pembuatan pre planning, persiapan penyajian, dan demonstrasi, tempat dan alat-alat lainnya disiapkan oleh peneliti. Pada tanggal 02 Mei 2020 dilakukan penyuluhan dan demonstrasi terapi senam otak.

\section{Tahap Pelaksanaan}

Kegiatan ini dengan pemberitahuan kepada klien dan orangtua klien, lalu dilanjutkan penyuluhan dan demonstrasi terapi senam otak.

3. Evaluasi

a. Struktur

Peserta hadir 1 orang yaitu laki-laki. Setting tempat sudah sesuai dengan rencana dan perlengkapan yang dilakukan untuk penyuluhan sudah tersedia dan sudah digunakan sebagaimana mestinya. Peran peneliti sebagai moderator, notulen, observer, dan juga fasilitator. Penggunaan bahasa yang dipraktekkan sudah komunikatif dalam penyampaian, klien dapat memahami dan dapat mempraktekkan kembali yang di demonstrasikan.

b. Proses

Pelaksanaan kegiatan dilaksanakan pukul 10.00 s/d 10.30 WIB. Sesuai dengan jadwal yang sudah ditentukan.

c. Hasil

1. Klien dapat memahami dan mengerti tentang terapi senam otak.

2. Klien dapat memahami dan mengerti tentang tujuan dilakukannya terapi senam otak.

3. Klien dapat memahami dan mengerti tentang manfaat dan teknik terapi senam otak.

4. Klien dapat memahami dan mengerti tentang langkah-langkah terapi senam otak.

\section{HASIL DAN PEMBAHASAN}

Pelaksanaan pemberian terapi senam otak dilaksanakan pada tanggal 02 Mei 2020 s/d 13 Mei 2020. Penelitian dilakukan selama 12 hari, setelah dilakukan pemberian terapi selama 12 hari didapatkan peningkatan konsentrasi belajar. Berikut pelaksanaan terapi senam otak :

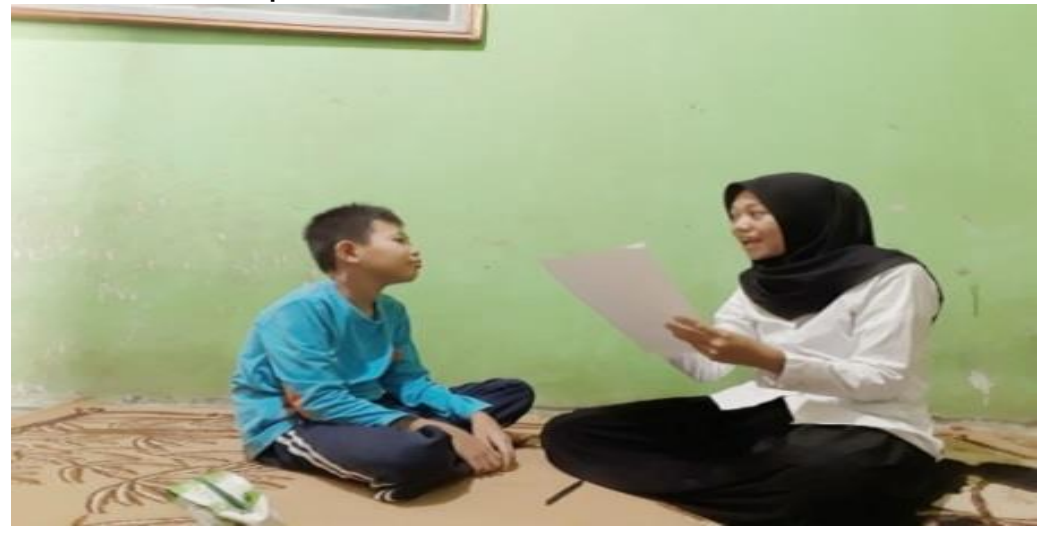



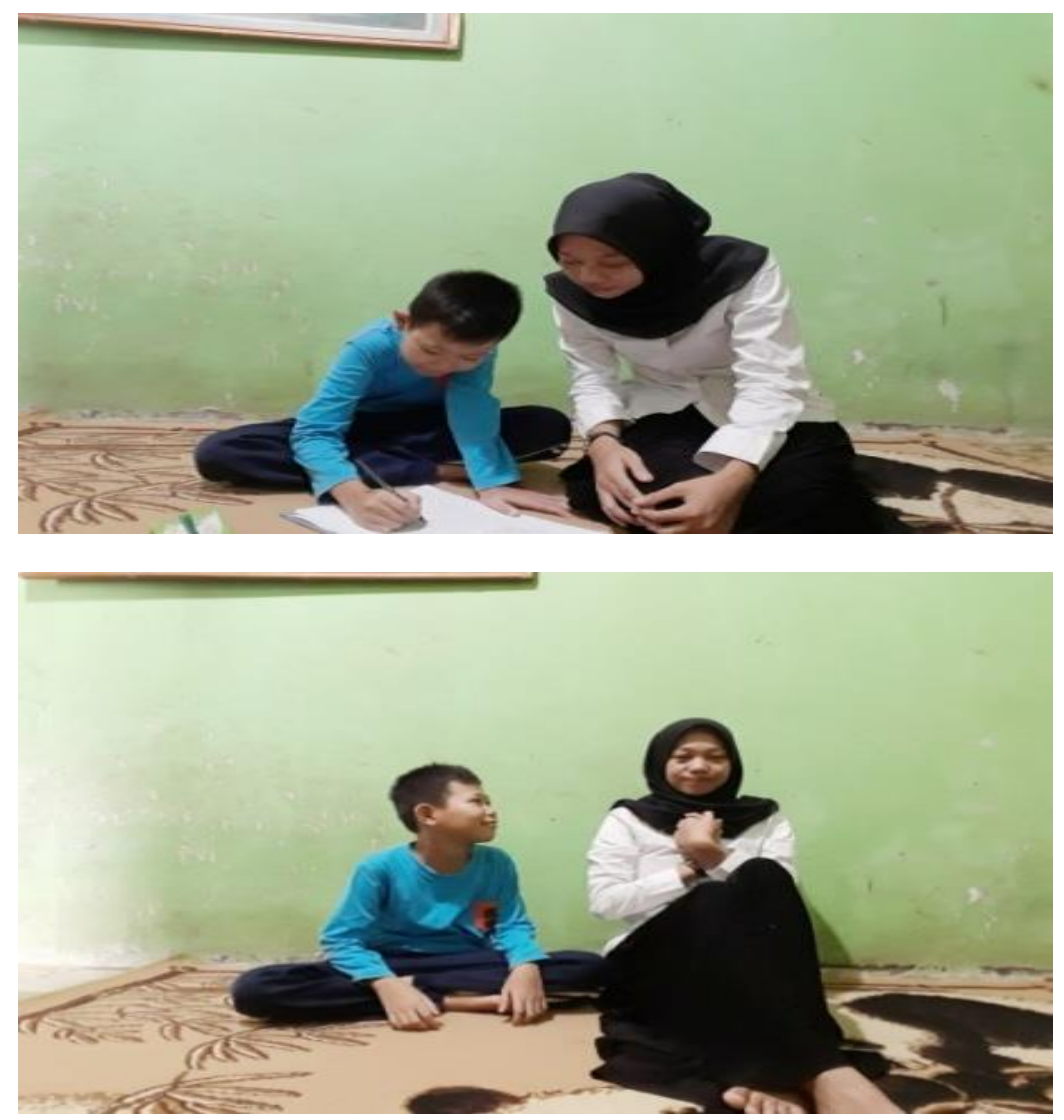

Gambar 4.1 Pelaksanaan Terapi Senam Otak

\section{KESIMPULAN}

Terapi non farmakologi pemberian terapi senam otak terbukti dapat meningatkan konsentrasi belajar. Terapi diberikan selama 12 hari, didapatkan hasil observasi yang dilakukan selama 12 hari terjadi peningkatan konsentrasi belajar pada An. V dimana sebelum diberikan terapi senam otak konsentrasi belajar anak dengan tingkat konsentrasi kurang dan setelah diberikan terapi menunjukkan tingkat konsentrasi klien sangat baik. Hal ini membuktikan bahwa terapi senam otak merupakan suatu prosedur/metode yang dapat digunakan untuk meningkatkan konsentrasi belajar pada anak dengan efektif.

\section{DAFTAR PUSTAKA}

Akmal, C. M., (2019). Pengaruh Minat Belajar Sejarah Terhadap Konsentrasi Belajar Sejarah Siswa Kelas Xi Ips 3 Sma Al-Azhar 3 Bandar Lampung Tahun Ajaran 2018/2019. Skripsi Publikasi.

Bili, L. D., \& Lengo, M. D. (2019). Efektivitas Senam Otak Dalam Meningkatkan Konsentrasi Belajar Siswa. Ciencias: Jurnal Penelitian Dan Pengembangan Pendidikan. 
Hamalik, O. (2011). Proses Belajar Mengajar . Jakarta: Bumi Aksara.

Ikbal, B. (2017). Pengaruh Senam Otak Terhadap Konsentrasi Belajar pada Mahasiswa Keperawatan UIN Alauddin Makassar (Doctoral dissertation, Universitas Islam Negeri Alauddin Makassar).

Maryani, I., et al. (2018). Model Intervensi Gangguan Kesulitan Belajar. Yogyakarta : K-Media.

Megawati, W., Ike, H., \& Maunaturrohmah, A. (2017). Pengaruh Senam Otak (Brain Gym) Terhadap Tingkat Konsentrasi Belajar Siswa Kelas Iv Sdn Wonoayu Kecamatn Pilangkenceng Kabupaten Madiun Jawa Timur. Jurnal Keperawatan, 13(1).

Naufal, A. D. F. (2016). Pengaruh Brain Gym terhadap Konsentrasi Belajar pada Siswa Kelas V SD di SDN 2 Sempusari Jember (Doctoral dissertation).

Prihastuti, S. U. (2010).Senam Otak Bersama Keluarga. Universitas Negeri Yogyakarta.

Santi, J. A. (2018). Efektifitas Brain Gym Terhadap Konsentrasi Belajar Anak Sd Di Sekolah Tahfidz Dan Non Tahfidz. SKRIPSI KEPERAWATAN.

Septian, R. (2018). Peningkatan Kemampuan Konsentrasi Melalui Penerapan Brain Gym: Studi Eksperimen Pada Siswa SDN Ciparay 07 Kab. Bandung (Doctoral dissertation, Universitas Pendidikan Indonesia).

Yanti, N., \& Bahri, S. (2018). Penggunaan Senam Otak Dalam Meningkatkan Konsentrasi Belajar Siswa Sd Negeri Ateuk Aceh Besar. JURNAL SULOH: Jurnal Bimbingan Konseling FKIP Unsyiah, 3(1). 